\title{
Perancangan Film Pendek Bertema Wisata dengan Pendekatan Storytelling sebagai Media Promosi Pulau Bawean
}

\author{
Dwi Prasetyo dan Denny Indrayana Setyadi. \\ Jurusan Desain Produk Industri, Fakultas Teknik Sipil dan Perencanaan, Institut Teknologi Sepuluh \\ Nopember (ITS) \\ J1. Arief Rahman Hakim, Surabaya 60111 Indonesia \\ e-mail: denny@prodes.its.ac.id
}

\begin{abstract}
Abstak-Bawean merupakan pulau yang berada di utara Pulau Jawa yang memiliki beragam pilihan objek wisata dengan keunggulan masing - masing yang menjadi daya tarik wisatawan mancanegara maupun lokal. Pulau Bawean dituntut untuk siap dalam berbagai aspek baik internal maupun eksternal salah satunya adalah promosi. Namun selama ini menurut dinas pariwisata sebagai penanggung jawab, upaya promosi yang dilakukan terhadap Pulau Bawean masih mengandalkan media konvensional dan tidak berjalan efektif. Hal ini mengakibatkan belum banyak yang mengetahui. Pulau Bawean membutuhkan media promosi yang dapat menggambarkan keindahan objek wisatanya secara nyata dalam hal ini adalah film. Sehingga diharapkan dapat berjalan efektif, dan dapat menarik wisatawan.

Metode penelitian yang digunakan pada tahap pengumpulan data diantaranya melakukan penggalian data melalui observasi langsung, kuisoner dan wawancara dengan stakeholder. Selanjutnya adalah menganalisis beberapa video dan film yang bertema promosi sebagai studi eksisting. Tahap selanjutnya, yaitu pengolahan data dimana nantinya akan dikaji dan dianalisis sehingga menjadi beberapa solusi penyelesaian dari masalah dalam perancangan ini.

Hasil akhir dari proses perancangan ini berupa film pendek bertema wisata dengan konsep Discover the Hidden Paradise yang menggambarkan Bawean sebagai pulau putri dapat memberikan image positif tentang keindahan pulau Bawean dan dalam pengembangannya dapat ditambahkan objekobjek wisata lain yang dapat dijadikan konten dalam sebuah film.
\end{abstract}

Kata Kunci-Bawean, Promosi, Film, Cerita

\section{PEndahuluan}

$\mathrm{P}$ ARIWISATA merupakan salah satu daya tarik di Indonesia yang sekarang telah menjadi sektor industri yang memiliki kemampuan atau peluang untuk berkembang pesat akibat dari banyaknya orang yang hobi untuk liburan dan travelling. Hal ini dibuktikan dengan kontribusi pariwisata terhadap perekonomian (PDB) nasional yang mengalami peningkatan dari tahun 2013 ke tahun 2014 ialah sebesar 0,21 persen dengan penghasilan devisa meningkat 0,64 miliar dollar AS.[1] Gresik adalah salah satu kota yang berada di daerah Jawa Timur yang merupakan kota industri dimana terdapat salah satu industri besar yang bertaraf internasional yaitu PT. Semen Gresik. Gresik juga terkenal lewat pariwisatanya. Salah satu objek pariwisata yang menjadi ikon kota Gresik adalah wisata religinya dimana ada dua tokoh ulama terkenal Walisongo yang dimakamkan disana yaitu
Sunan Giri dan Sunan Maulana Malik Ibrahim sehingga membuat gresik memiliki sebutan sebagai kota para wali. Selain pariwisata tersebut sebenarnya Kabupaten Gresik masih memiliki potensi wisata lain yang sedang tahap perencanaan sebagai ikon pariwisata baru yang ada di Gresik bahkan ada di Jawa Timur. Objek pariwisata tersebut adalah Pulau Bawean

Pulau Bawean adalah pulau yang berada di utara kabupaten Gresik yang berjarak $120 \mathrm{~km}$ dari pulau jawa. Bawean memiliki dua kecamatan yaitu kecamatan Sangkapura dan kecamatan Tambak dimana disetiap kecamatanya memiliki beberapa objek wisata yang ditawarkan. Dalam Laporan Kajian Pengembangan Potensi Pariwisata Kabupaten Gresik oleh Badan Perencanaan Pembangunan dan Pengembangan Daerah Kabupaten Gresik Tahun 2011 mengatakan bahwa terdapat sepuluh tujuan wisata lingkungan yang dapat dikunjungi oleh wisatawan lokal maupun mancanegara. Diantaranya adalah empat wisata lingkungan daratan, empat wisata bahari, dan dua wisata pantai dimana semua objek wisata tersebut masih alami dan tergolong sebagai wisata alam.[2]

Selain itu di Bawean juga terdapat wisata menuju sentra kerajinan tangan yang khas yaitu anyaman tas dan tikar dari daun pandan, disana wisatawan dapat belajar bagaimana cara untuk menganyam pandan menjadi sebuah tas yang unik. Sebagai pulau yang memiliki beberapa objek wisata Pulau Bawean dituntut untuk siap dalam berbagai aspek, baik aspek internal contohnya sarana prasana yang mendukung sampai aspek eksternal yaitu promosi.

Pulau Bawean selama ini dalam mempromosikan wisatanya mengandalkan 3 Media yaitu media brosur, buku profil wisata, dan website yang dikelola oleh ormas Bawean. Namun menurut Kepala UPT Pariwisata Bawean promosi wisata Bawean dengan 3 media tersebut belum maksimal dimana selama ini brosur dan buku profil hanya disebar ketika ada pameran wisata dan disebar beberapa saat ada wisatawan yang mengunjungi Bawean, sementara itu website Bawean ini berisi tentang berita-berita umum yang ada di Bawean sehingga membuat website tersebut bukanlah tujuan utama yang berisi informasi tentang wisata.[3]

Terkait dengan hal diatas media yang dapat mengakomodasi kebutuhan ini adalah media audiovisual dimana media ini menampilkan gambar bergerak dan efek suara secara bersamaan sehingga terasa lebih hidup dan realistis. Film adalah media komunikasi yang bersifat 
audiovisual untuk menyampaikan suatu pesan kepada sekelompok orang yang berkumpul di suatu tempat tertentu. (Effendy, 1986: 134). Pesan film pada komunikasi massa dapat berbentuk apa saja tergantung dari misi film tersebut. Akan tetapi, umumnya sebuah film dapat mencakup berbagai pesan, baik itu pesan pendidikan, hiburan dan informasi. Pesan dalam film adalah menggunakan mekanisme lambang-lambang yang ada pada pikiran manusia berupa isi pesan, suara, perkataan, percakapan dan sebagainya yang dikemas dalam sebuah plot atau alur cerita. Dalam kenyataanya film juga mampu mencakup pesan berupa promosi objek-objek pariwisata misalnya didalam adegan sebuah film diambil di tempat yang memiliki pemandangan yang indah. Hal ini akan mengakibatkan penonton merasa tertarik dengan visual yang disuguhkan dan penasaran lokasi tersebut sehingga mereka mulai mencari lokasinya dan suatu saat nanti akan mengunjunginya. Di Indonesia sendiri beberapa produksi film mulai dibubuhi pesan berupa promosi objek-objek wisata. Beberapa diantaranya menggunakan objek berupa daerahdaerah yang belum banyak diketahui orang tentang objekobjek wisatanya yang eksotis sehingga menambah nilai dari film tersebut. Selain itu ada beberapa film juga mengambil objek dari daerahnya berupa wisata budaya, wisata kuliner, wisata sejarah tergantung dari dimana lokasi daerah tersebut.

Dalam hal ini Pulau Bawean memiliki objek-objek wisata yang belum diketahui namun memiliki potensi keindahan alam yang menjadikannya memiliki nilai lebih untuk di promosikan dengan cara diabadikan dalam film. Contohnya adalah keindahan Pantai Gili Noko dimana hamparan pasir putih luas yang membentuk pulau kecil lalu keindahan taman bawah laut dan sebagainya. Selain itu menurut kepala UPT Pariwisata Bawean menginginkan media promosi yang dapat menggambarkan identitas pulau Bawean sebagai Pulau Putri dimana memiliki arti Bawean kebanyakan memiliki penduduk wanita daripada pria dikarena banyak penduduk prianya yang memilih merantau keluar pulau, selain itu pulau putri juga dapat diartikan sebagai keindahan objekobjek pariwisatanya dan keramahan penduduknya. Nantinya semua aset tersebut akan diolah dan dikembangkan sehingga menjadi sebuah plot atau alur cerita dan di produksi menjadi sebuah film. Dengan adanya media promosi berupa film ini diharapkan dapat menjawab permasalahan promosi wisata Bawean dengan cara dipertontonkan secara luas dan dengan film ini dapat menyampaikan pesan bahwa Bawean memiliki masyarakat yang baik dan ramah serta memiliki objek-objek pariwisata yang indah dan patut untuk dijadikan salah satu destinasi wisata favorit.

\section{A. Batasan Masalah}

Dari latar belakang diatas penulis mengidentifikasi beberapa permasalahan yang memiliki tingkat urgenitas dari segi desain komunikasi visual

a. Belum terkelola secara maksimal objek-objek wisata yang ada di pulau Bawean

b. Media promosi yang digunakan oleh pulau Bawean adalah brosur, buku profil dan website dimana penyebarannya masih sangat terbatas untuk sampai ke masyarakat luas c. Belum ada media promosi yang dapat menggambarkan identitas pulau Bawean sebagai pulau putri dimana hal tersebut menggambarkan keindahan objek-objek pariwisatanya serta keramahan penduduk lokal

d. Belum ada media promosi Bawean yang dapat menggambarkan aktifitas-aktifitas yang dapat dilakukan di setiap objek-objek pariwisatanya

\section{B. Rumusan Masalah}

Bagaimana merancang film yang dapat merepresentasikan identitas Bawean sebagai Pulau Putri sehingga dapat membantu dalam upaya mempromosikan wisata?

\section{Tujuan}

Tujuan perancangan dalam penulisan ini adalah sebagai berikut:

1. Merancang film bertema wisata yang dapat menggambarkan keindahan-keindahan setiap objek pariwisata di Pulau Bawean, keramahan penduduknya, serta aktifitas-aktifitas yang dapat dilakukan wisatawan disana

2. Meningkatkan kualitas promosi kabupaten Gresik di bidang digital sehingga dapat membantu memperkenalkan wisata Pulau Bawean secara meluas.

\section{URAIAN PENELITIAN}

A. Landasan Teori

a. Tinjauan Subyek Desain

- Video

Video menurut beberapa praktisi adalah penggabungan dari beberapa elemen pendukunh yang nantinya akan berinteraksi satu dengan yang lain untuk membentuk sebuah video atau film yang memiliki cerita. Kata-kata dan gambar yang dirancangkan sedemikian rupa diharapkan dapat memberi dampak berupa emosi penonton atau dampak lain diinginkan oleh pembuat video. Elemenelemen ini tidak dapat berdiri sendiri dalam pembuatan video atau film.

- Sinematografi

Sinematografi adalah meliputi semua pekerja dan aspek dari proses pengambilan gambar dalam sebuah film atau video, mulai dari teknis penggunaan kamera dan pencahayaan, sudut pandang, dan jarak. Unsur sinematografi secar umum dapat dibagi menjadi tiga aspek yaitu kamera dan film, framing, serta durasi gambar. Kamera dan film mencakup teknik-teknik yang digunakan dalam menggunakan kamera, seperti warna, kecepatan gerak gambar, dan sebagainya, framing adalah hubungan objek yang akan diambil dengan kamera, seperti batasan wilayah gambar pada kamera atau frame, jarak, ketinggian, pergerakan kamera, dan seterusnya. Sementara durasi gambar mencakup lamanya sebuah objek diambil gambarnya oleh kamera.[4]

\section{- Storytelling}

Story dapat didefinisiakan sebagai rangkaian kejadian cerita dan unsur naratif dengan tujuan untuk 
menyampaikan sebuah cerita baik dalam bentuk kata-kata, gambar, video, mauun suara. Dalam dunia pemasaran produk atau marketing mulai menggunakan pendekatan storytelling sebagai usaha untuk mempromosikan serta memasarkan produk mereka. Kesukaan manusia terhadap storytelling tak lepas dari peran otak manusia yang lebih mudah menyerap cerita disbanding sederet data dan fakta.

\section{B. Studi Eksisting}

\section{- Video Promosi "Wonderful Indonesia-Lombok"}

Konsep pada video promosi ini adalah menggambarkan Lombok yang memiliki beragam objek pariwisata yang indah dan unik. Seperti pantai-pantai karena pada dasarnya Lombok adalah sebuah pulau yang memiliki objek wisata pantai yang banyak. Selain objek-objek wisata pantai juga digambarkan dengan wisata air terjun dan keragaman flora dan fauna yang secara tidak langsung menggambarkan bahwa objek-objek wisata di Lombok masih alami, bersih, indah dan nyaman. Hal ini didukung dengan music atau scoring yang sesuai dengan image Lombok sehingga membawa mood audience seperti berada di Lombok dan mengikuti alur cerita.didukung dengan narasi bahasa inggris sesuai untuk target mereka yaitu wisatawan mancanegara.

Alur dari video ini adalah berawal menggambarkan kekayaan pariwisata serta digabung dengan kebudayaan lokal seperti menggambarkan warga sekitar sedang menenun kain, membuat kerajina tanah liat, dan pengerajin mutiara. Selanjutnya menggambarkan flora dan fauna yang meberikan kesan dekat dengan alam dan masih alami. Lalu menggambarkan kegiatan wisatawan yang dilakukan dilombok seperti snorkeling menikmati terumbu karang dll

Dalam pengambilan gambar terdapat perpaduan antara longshot,medium shot, close up dan extreme closeup sesuai dengan kebutuhan yang ingin ditampilkan dalam video. Tone berubah-rubah disesuaikan dengan mood yang ingin ditampilkan pada audience.

\section{- Video Promosi "I Hate Thailand"}

Konsep pada video ini adalah lebih menceritakan tentang sisi pariwisata Thailand dari penduduknya. Menggambarkan seorang wisatawan asing yang baru pertama kali mengunjungi Thailand namun ia harus kehilangan barang berharganya ketika menikmati wisata disana. Yang tersisa dari barang-barang yang hilang tersebut adalah beberapa uang koin yang tidak cukup untuk kehidupan untuk saat itu ia berkata benci Thailand. Semua orang yang pertama kali ia temui tidak dapat membantunya untuk menyelesaikan masalah ini. sampai akhirnya dia bertemu wanita asli Thailand dan membatunya. Sedikit demi sedikit dia sadar sebenarnya warga Thailand ternyata sangat ramah dan sangat baik yang akhirnya dia memutuskan untuk tinggal di Thailand karena cinta dengan kehangatan masyarakat disana.

\section{METODE PERANCANGAN}

\section{A. Metode Penelitian}

a. Data Primer

- Observasi dan Kuesioner Peneliti melakukan observasi langsung dengan pergi langsung ke pulau Bawean dengan mengamati dan mempelajari hal-hal yang berhubungan dengan wisata yang ada di pulau Bawean mulai dari perjalanan menuju pulau Bawean, perjalanan menuju objek-objek wisata,, memahami lokasi objek wisata yang akan membantu untuk menentukan strategi bagaimana nantinya tahap produksi video yang dilakukan peneliti. Mulai dari mengobservasi spot-spot indah di Bawean serta mengenal medan objek wisata Bawean

Kuisoner ini disebar kepada masyarakat terutama yang daerah Surabaya, Malang, Gresik dan Sidoarjo baik laki-laki maupun perempuan dengan rentang usia 15-40 tahun. Tidak ada spesifikasi dalam pekerjaan, tingkat pendidikan, dan pengeluaran. Diutamakan kepada masyarakat yang suka traveling atau berwisata. Kuisoner dilakukan untuk memperoleh data sebagai berikut:

1. Seberapa masyarakat mengenal wisata pulau Bawean.

2. Objek wisata favorit pengunjung wisata pulau Bawean.

3. Kegiatan yang dilakukan oleh pengunjung.

4. Interest dari target audience.

5. Media yang paling menarik minat audience untuk promosi wisata pulau Bawean.

6. Hal-hal menarik yang dapat dijadikan acuan dalam video promosi yang dibuat .

\section{- Depth Interview}

Wawancara mendalam dilakukan terhadap beberapa pihak antara lain :

1. Bapak Imran Rasyidi, S.sos selaku kepala UPT Pariwisata Pulau Bawean

2. Bapak faisal, Staff UPT Pariwisata Pulau Bawean

3. Muhammad Andri, Guide dari Bawean Tourism

\section{b. Data Sekunder}

Data sekunder adalah data yang diambil tidak secara langsung dari sumbernya. Sumber data sekunder yang digunakan dalam perancangan ini dalah sebagai berikut :

1. Databases dari penelitian terdahulu (Mahasiswa atau dosen)

2. Teori-teori pendukung dan literature-literatur yang sesuai

3. Studi komparator dan eksisting

4. Informasi tentang objek-objek wisata di pulau Bawean dari travel dan paket tour dari internet.

\section{B. Konsep Desain}

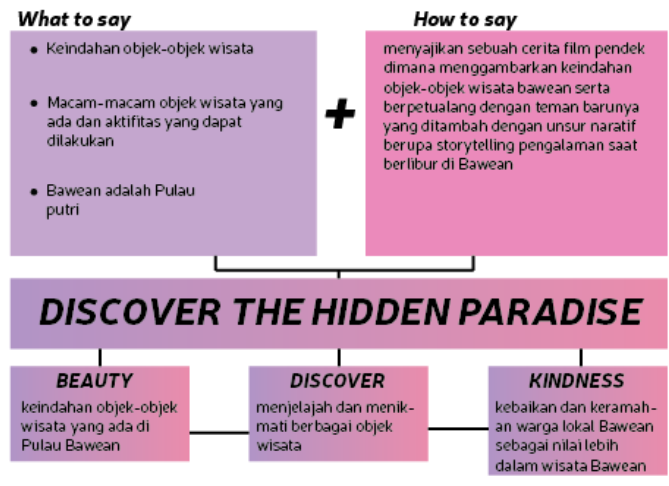

Gambar 1. Chart Flow Konsep Desain 
Setelah menganalisis hasil dari penilitian yang dilakukan oleh penulis dapat ditentukannya konsep dalam perancangan ini yaitu "Discover the hidden paradise". Konsep ini dibuat berdasarkan hasil perumusan masalah dan kebutuhan yang dihadapi oleh objek desain yaitu objek-objek wisata yang ada di Bawean masih belum banyak orang yang mengetahuinya mulai dari apa saja objek-objek pariwisatanya sampai apa saja yang dapat dilakukan di objek wisata tersebut konsep dapat dilihat dalam gambar 1.

Selain itu media promosi yang sudah ada pun belum dapat menggambarkan identitas asli pulau Bawean sebagai pulau putri. Dalam konsep ini terdapat tiga kata kunci yang merupakan pesan yaitu beauty, discover, dan kindness. Kata kunci tersebut mewakili dari setiap kebutuhan dari permasalahan di Bawean yang ingin memperkenalkan keindahan masing-masing objek wisatanya mulai dari wisata alam berupa wisata darat dan laut sampai wisata kerajinan tangan asli Bawean, lalu menggambarkan bagaimana kegiatan petualangan menuju objek-objek pariwisata tersebut dikarenakan objek-objek pariwisata di Bawean masih alami. Lalu menggambarkan kegiatan setelah sampai di masingmasing objek wisata disana. Selanjutnya konsep ini juga ingin menggambarkan baik dan ramahnya warga lokal disana dalam menyambut wisatawan baru yang mengunjungi pulau Bawean

Setelah menyimpulkan beberapa analisis dari hasil penggalian data dapat di tentukan segmentasi untuk audience dari film ini adalah audience dengan rentang umur 20-25 tahun dengan beberapa karakteristik berupa memiliki hobi traveling, sering meluangkan waktu untuk berlibur, suka berwisata alam dan suka berwisata dengan teman-temannya. Hal ini dikarenakan untuk berwisata ke Bawean memerlukan minimal 3 hari dan lokasinya yang jauh. Namun dalam segmen tersebut menurut kuisoner, calon audiens dalam sebulan dapat melakukan lebih dari 4 kali untuk berwisata didalam kesibukannya dengan pekerjaan. Hal ini menandakan walau mereka memiliki kesibukan lain, dengan hobinya traveling mereka akan meluangkan waktu untuk berwisata ke obyekobyek wisata alam.

\section{A. Kriteria Desain}

\section{PEMBAHASAN DESAIN}

\section{- Storyline}

Dalam pembuatan film ini membutuhkan cerita dimana cerita tersebut nantinya sebagai media pembawa konten dan pesan yang ingin disampaikan oleh penulis kedalam film tersebut. Pesan yang ingin disampaikan adalah Bawean memiliki banyak objek pariwisata indah yang dapat dikunungi wisatawan. Film ini juga mampu memberi gambaran tentang objek-objek wisata disana dan apa saja yang dapat dilakukan wisatawan ketika mengunjungi Bawean. Selain itu Bawean juga memiliki warga lokal yang ramah terhadap wisatawan yang baru mengunjungi Bawean. Pesan-pesan tersebut digabungkan dengan konten-konten yang telah ditentukan oleh penulis.

\section{- Enviromental dan Setting}

Dalam proses produksi atau shooting diperlukan adanya setting tempat yang disesuaikan dengan narasi pada storyline. Setting tempat ini berguna untuk membuat video lebih memiliki nuansa yang dapat membawa dan memainkan perasaan audiens. Pada video ini kebanyakan menggunakan setting tempat asli seperti pantai, bebatuan, dan lain-lain karena dalam konten-konten dari video ini adalah berupa objek-objek wisata

Selain menggunakan setting asli dari objek-objek wisata yang ada di Pulau Bawean beberapa Scene juga memelukan setting buatan guna mendapatkan gambar yang sesuai dengan narasi.

\section{- Karakter/Talent}

Pemilihan penggunaan talent dalam video ini adalah berdasarkan konsep desain yang telah dibuat. Tema yang digunakan adalah traveler seperti orang yang suka berpetualang bersama teman dan menjelajah ke suatu tempat baru yang mana dapat mempengaurhi dalam pemilihan karakter talent seperti berapa jumlah talent yang digunakan, fisik dari masing-masing talent danl lain-lain.

\section{- Suara/SFX}

Suara atau soundeffect adalah bagian yang mampu membawa perasaan audiens sehingga dalam pemilihannya membutuhkan kategori-kategori yang dapat menjadi acuan dalam pemilihan sound untuk background dalam video ini.

\section{a. Background}

Berdasarkan studi komparator background sound dalam video promosi adalah uplifting atau kecenderungan untuk biasa lalu naik ditengah musik dan turun pada akhir musik. Kategori yang terpilih adalah musik yang bertema petualangan, happy dan bertema relaxing. Diharapkan dengan dipilihnya music tersebut audiens akan terbawa secara emosi dengan video promosi ini

\section{b. Ambient}

Selain suara background dalam video ini juga menambahkan suara-suara ambient untuk menambah suasana seperti ambient ombak ketika muncul Scene ombak, suara kicauan burung ketika muncul Scene berjalan didalam hutan,dan lain-lain. Sound tersebut bisa melalui source asli video atau mengunduh melalui internet.

\section{c. Voice Over}

Untuk membawakan narasi yang ada atau menjelaskan Scene dengan kata-kata penulis menggunakan voice over. Narasi dari voiceover ini diambil dari cerita pengalaman dari masing-masing pemeran baik wanita dan pria. Mereka berdua bercerita tentang keseharian mereka dan pengalaman mereka layaknya mereka bercerita kepada penonton atau melakukan monolog. Bahasa yang digunakan pun Bahasa bercerita seharihari sehingga lebih bersifat seperti bercerita langsung kepada audiens

\section{- Sinematografi \\ - Kamera Video}

Jenis kamera yang digunkana dalam perancangan ini adalah kamera DSLR (Digital Single Lens Reflect), dengan merk dan tipe Canon EOS 60D dan Sony Alpha 7 yang menggunakan lensa standart kit 18-200 mm digunakan untuk mengambil gambar medium shot, long shot dan closeup shot, 
selain itu penulis juga menggunakan lensa wide untuk mengambil shot longshot panorama sehingga lebih lebar. Untuk extreme closeup menggunakan lensa $50 \mathrm{~mm}$.

Selain menggunakan kamera DSLR juga menggunakan action camera karena beberapa adegan membutuhkan untuk masuk dalam air. Selain bentuknya kecil kamera ini juga berguna untuk shot-shot wide dan underwater. Ada juga menggunakan Drone untuk penggambilan gambar lansekap

\section{- Framing}

Aspect ratio yang digunakan pada video ini adalah $720 \mathrm{p}$ dengan frame 25fps widescreen dikarenakan dalam pengambilan gambar banyak menggunakan landscape yang luas dengan efek widescreen akan lebih terasa cinematic. Jarak kamera terhadap obyek :

\section{- Extreme Long Shot}

Teknik ini dapat digunakan untuk mengambil pemandangan yang sangat jauh dari suatu objek dimana dalam perancangan ini digunakan untuk mengambil pemandangan pantai gili noko, bukit gundul, dan tanjung ge'en dengan menggunakan drone. Hasil gambar terlihat dalam gambar 2.

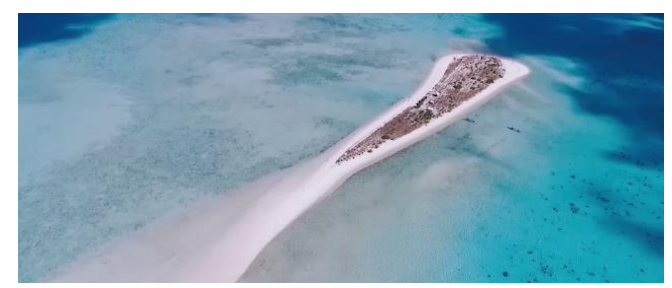

Gambar. 2. Penggunaan extreme long shot

\section{- Long Shot}

Teknik ini digunakan untuk membantu komposisi antara aktor engan lingkungannya sehingga memiliki keseimbangan dalam framenya teknik ini digunakan dalam beberapa scene yang menggambarkan talent sedang berfoto-foto di bukit gundul. Teknik ini menggunakan bantuan kamera Sony alpha dengan lensa 18-200.Hasil dapat dilihat dalam gambar 3 .

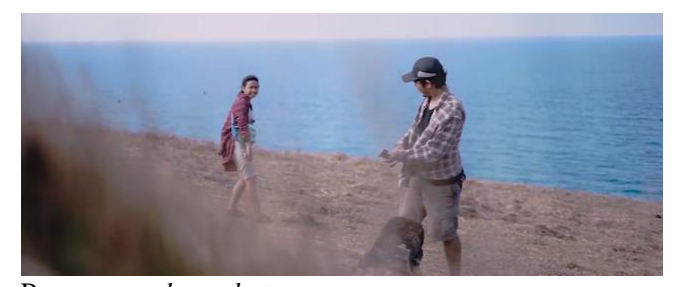

Gambar. 3. Penggunaan long shot

\section{- Medium Close-Up}

Medium Close-Up digunakan untuk memperlihatkan lebih detil ekspresi seorang talent dalam suatu adegan dalam hal ini ada beberapa adegan dalam film ini seperti adegan ketika talent pria kebingungan tasnya yang hilang. Teknik ini digunakan dengan bantuan lensa $50 \mathrm{~mm}$ karena ingin memfokuskan pada wajah talent. Hasil dapat dilihat dalam gambar 4.

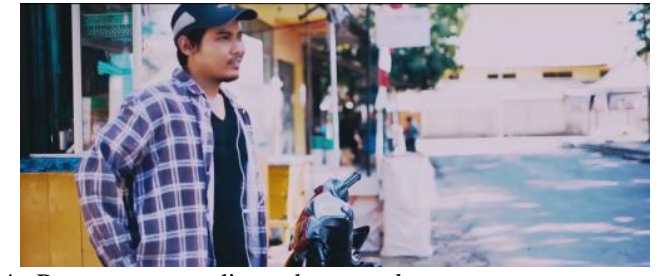

Gambar. 4. Penggunaan medium close-up shot.

\section{- Close-Up}

Digunakan untuk memperlihatkan ekpresi wajah dengan jelas serta gesture yang mendetil. Close-up nantinya juga memperlihatkan detil sebuah benda atau obyek.dalam film ini teknik ini digunakan saat mengambil detail saat menganyam tas anyaman, seperti terlihat dalam gambar 5 .

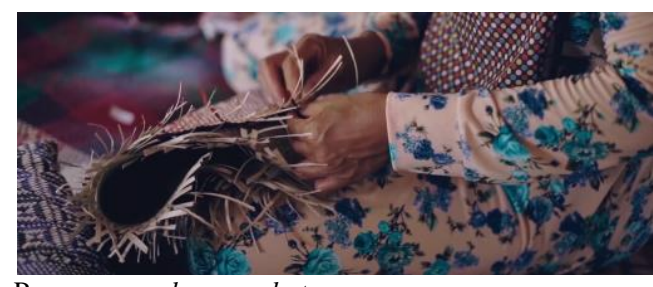

Gambar. 5. Penggunaan close-up shot

\section{- Durasi}

Durasi yang digunakan dalam perancangan ini berdasarkan jumlah konten dan studi komparator yang dilakukan oleh penulis adalah antara 3 sampai 5 menit untuk sebuah video promosi. Kebanyakan sebuah video promosi berdurasi antara 3-7 menit namun tersebut menyesuaikan konten dan cakupan. Contohnya adalah sebuah video promosi yang membahas objek wisata di suatu negara yang memiliki durasi 10 sampai 15 menit dikarenakan cakupan yang luas dan konten yang banyak. Jika menggunakan durasi yang panjang namun cakupan atau konten tidak seimbang dampaknya akan membuat audiens bosan. Tempat dimana video ini akan ditayangkan juga mempengaruhi durasinya

\section{- Lighting}

Pencahayan pada video ini menggunakan natural light atau cahaya asli dari cahaya matahari dengan bantuan beberapa reflector untuk memantulkan cahaya tersebut. Namun adakalanya cahaya matahari memberikan efek overlight sehingga muncul shadow yang terlihat ketika mengambil gambar pada talent. Hal ini bisa diperbaiki dengan menggunakan lampu tambahan atau menggunakan reflector.

\section{- Editing}

Transisi yang digunakan adalah cut, fade in dan fade out, dan dissolve sesuai dengan kebutuhan yang ditunjukkan dalam narasi dan storyboard. Editing ini menggunakan software edit seperti Adobe Premiere, dan Adobe After Effect untuk proses coloring dan penambahan elemen-elemen visual seperti pengaturan cahaya dan motion graphic 


\section{B. Design Final}

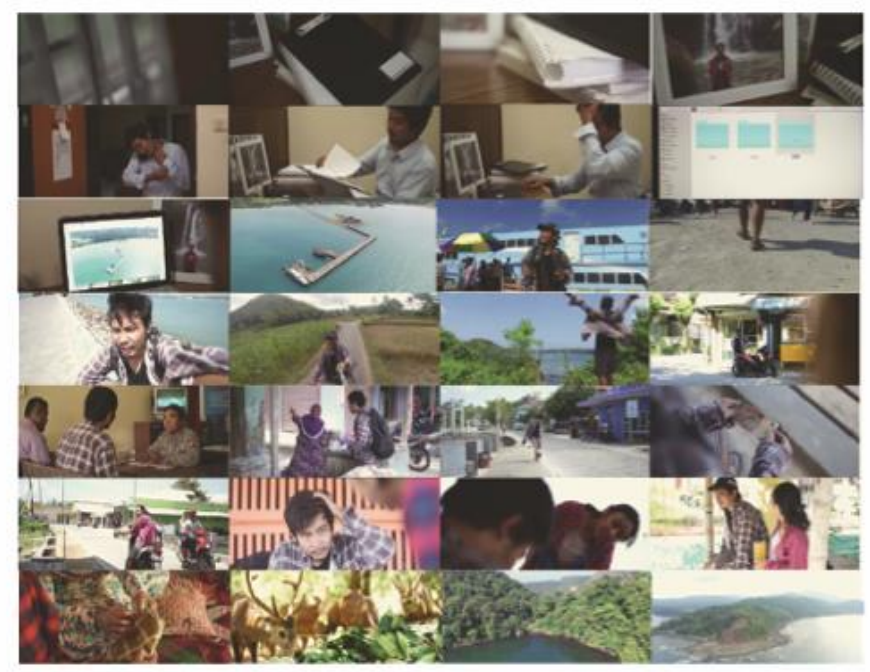

Gambar. 6. Screencapture video (a).

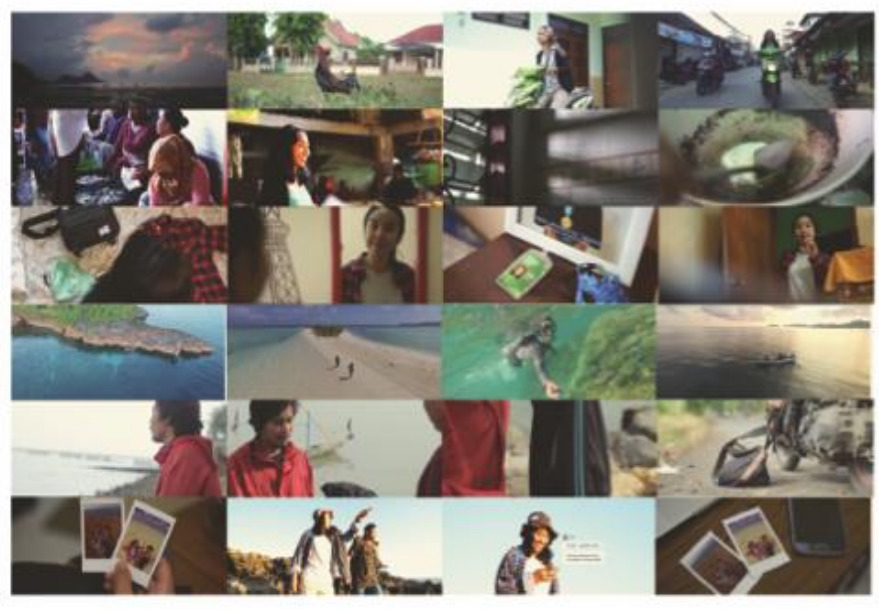

Gambar. 6. Screencapture video (b).

\section{Strategi Penempatan}

- Youtube (gambar 7)

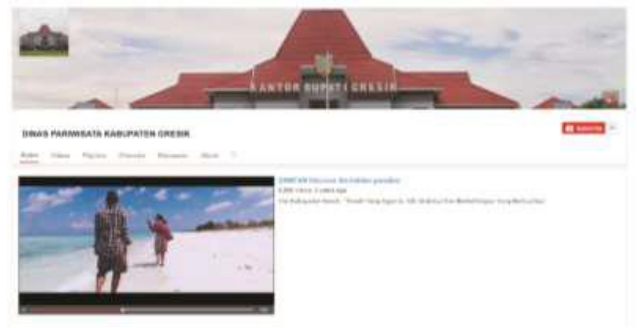

Gambar. 7. Implementasi pada Youtube

- Website Dinas Pariwisata dan Website Travel Bawean (gambar 8)
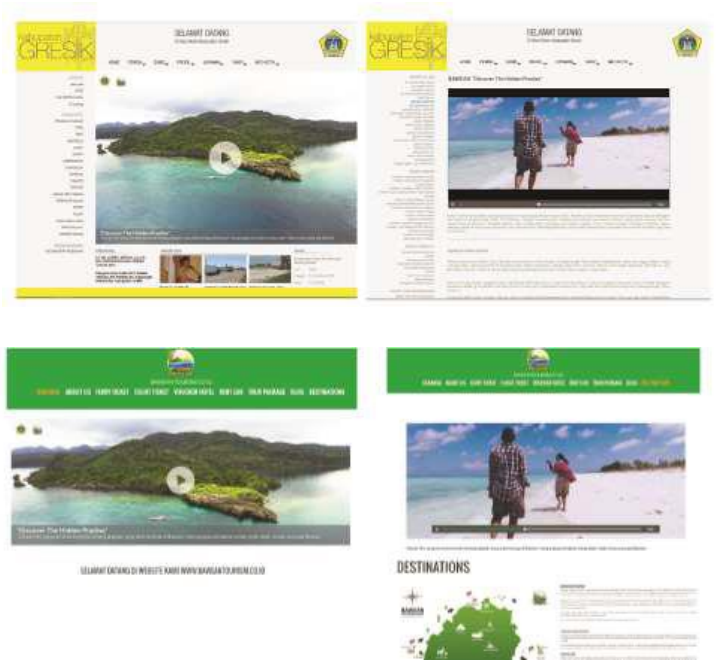

Gambar. 8. Implementasi pada home website travel Bawean dan pada tab pariwisata Bawean

\section{- Event}

Selain video utama juga terdapat video turunan berupa potongan adegan adegan dari film tersebut yang nantinya dapat membantu mempromosikan film ini salah satunya adalah memanfaatkan event sebagai sarana menayangkan video promo wisata Pulau Bawean seperti pada Pameran pariwisata (Regional, Nasional, International), acara acara tahunan yang telah direncanakan Dinas Kebudayaan dan Pariwisata Gresik dan Jawa Timur. Dalam acara tersebut video teaser ditayangkan didalam booth pameran lalu untuk versi lengkap dari film tersebut ditayangkan pada panggung utama saat mempresentasikan wisata gresik

\section{- Media Sosial}

Untuk mengundang penonton agar melihat film tersebut adalah dengan cara membuatnya viral. Hal ini dilakukan dengan cara membuat teaser dari film tersebut. Teaser dibuat dengan durasi 15 detik dan 30 detik agar sesuai dengan media penempatannya. Untuk di youtube iklan tersebut dapat diletakkan pada iklan youtube yang sesuai dengan kategori dari film tersebut yakni tentang wisata. Maka setiap orang yang mencari video bertema wisata iklan tersebut akan keluar. Selain itu iklan ini juga bisa masuk dalam berbagai media sosial

Penjadwalan media atau Media Strategic Planer merupakan teknik pemasaran untuk mengkerucutkan objek sasaran pemasaran dan serta untuk mengoptimalkan biaya serta strategi pemasaran yang ideal. Penjadwalan media yang baik akan mendukung tersampaikannya pesan kepada audiens dengan efektif dan baik pula. Dalam perancangan ini teaser tersebut ditayangkan dibeberapa media sosial seperti iklan youtube, facebook dan iklan Instagram dimana mengikuti jadwal libur nasional, hari libur panjang/cuti, serta mengikuti keadaan cuaca dan ramainya pengunjung yang ke Bawean. Berikut adalah perencanaan iklan yang tayang dalam periode januari sampai desember, dapat dilihat dalam gambar 9 dan gambar 10 . 


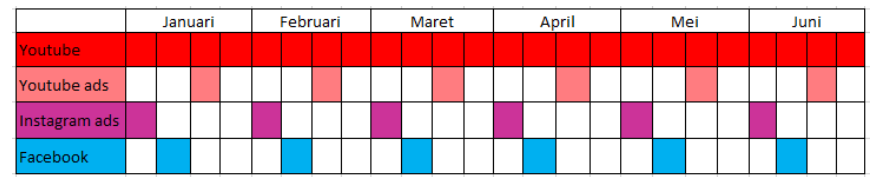

Gambar. 9. Proses Screening Film

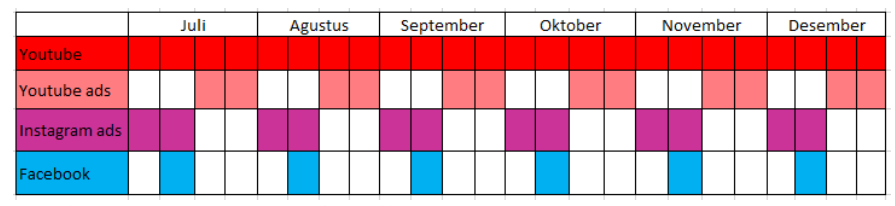

Gambar. 10. Proses Screening Film

\section{Post Test}

Setelah desain selesai dibuat maka selanjutnya penulis melakukan user testing dimana hal ini dilakukan untuk mengetahui apakah desain tersebut dapat menyelesaikan masalah dan menjawab kebutuhan dari objek desain tersebut. User testing dilakukan ke beberapa orang dengan karakteristik sesuai dengan target segmentasi dari perancangan ini. Kondisi screening dapat dilihat dalam gambar 11.
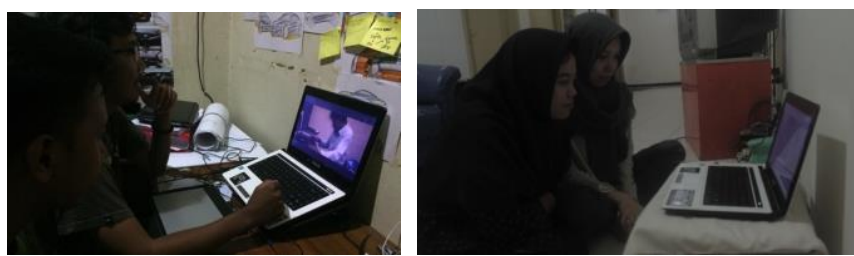

Gambar. 11. Proses Screening Film

Hasil dari user testing yang dilakukan oleh penulis adalah sebagai berikut

- Setelah film di pertontonkan kepada beberapa target audiens, sebagian besar dari mereka memahami jalan dan alur cerita dari film tersebut mulai dari pemutaran video pertama dan kedua yang memiliki hubungan satu sama lain.

- Kesan pertama kali setelah melihat video tersebut adalah mereka takjub dengan keindahan alam Bawean karena memang dari awal kebanyakan belum tahu tentang apa saja wisata yang ada disana. Wisata alam di Bawean terlihat alami dan belum terjamah sehingga masih memiliki keindahan sebagai wisata alam

- Ketika ditanya apakah mereka tertarik untuk berkunjung ke Bawean jawabannya adalah semua tertarik untuk kesana karena memang mereka hobi untuk berpetualang yang memiliki wisata alam apalagi wisata alam yang masih alami dan belum terkenal.

- Ada beberapa kritik untuk film tersebut dimana selebihnya dari segi editing yaitu dari masalah scoring. Suara monolog dari pemeran utama kadang bersamaan dengan suara background music sehingga kadang beberapa kata-kata monolog tidak begitu jelas

\section{KESIMPULAN DAN SARAN \\ A. Kesimpulan}

Berdasarkan hasil analisis karya tulis "Perancangan film pendek bertema wisata dengan pendekatan storytelling sebagai media promosi Pulau Bawean" dapat diambil sebuah kesimpulan bahwa promosi khususnya dalam bentuk audio visual menjadi hal yang menarik dan efektif untuk meningkatkan minat masyarakat maupun wisatawan mengunjungi Pulau Bawean. Selain untuk mempromosikan destinasi wisata Pulau Bawean, juga untuk memberi citra yang baik kepada wisatawan.

Dari hasil user testing yang dilakukan terkait perancangan film pendek bertema wisata dengan pendekatan storytelling sebagai media promosi Pulau Bawean, didapat bahwa film ini telah mampu menggambarkan keindahan setiap objek pariwisata di Pulau Bawean, keramahan penduduk, serta aktifitas - aktifitas yang dilakukan wisatawan sesuai dengan harapan dari stakeholder. Dengan adanya film pendek ini juga dirasa telah mampu meningkatkan kualitas promosi Kabupaten Gresik untuk membantu memperkenalkan wisata Pulau Bawean secara meluas. Image positif tentang keindahan Pulau Bawean juga dapat tersampaikan kepada audience, sehingga memberi pengaruh kepada mereka tertarik mengunjungi Pulau Bawean.

\section{B. Saran}

Disetiap Saran untuk perancangan film bertema wisata dengan pendekatan storytelling sebagai promosi wisata pulau Bawean yang didapat melalui proses user testing ini masih memiliki kekurangan yang nantinya akan dapat dikembangkan dari segi desain maupun konten.

Dalam film tersebut jika lebih banyak ditambah konten tentang objek-objek pariwisata lain akan lebih baik, contohnya ada beberapa lokasi porsi dari tiap Scene masi kurang sehingga penonton belum puas untuk melihat lebih jauh keindahan di tiap sisi dari objek pariwisata tersebut. Dalam pengembangannya diharapkan terdapat juga video-video lain yang berseri tentang budaya dan keseharian warga Bawean karena dalam film tersebut sisi dari budaya dan keseharian masyarakat Bawean terlihat tidak banyak.

\section{DAFTAR PUSTAKA}

[1] Asdhiana, I. M. (2014, Februari 4). "Tahun 2014 sektor pariwisata semakin cerah". [online] Retrieved from travel.kompas.com: http://travel.kompas.com./read/2014/02/04/0927583/tahun.2014.sektor. pariwisata.semakin.cerah

[2] Dahlia, W. P. (2013). "Pulau Bawean potensi wisata yang luar biasa". [online] Retrieved from Bawean.net: http://www.Bawean.net/2013/07/pulau-Bawean-potensi-wisata-luarbiasa.html

[3] Darrisma, A. A. (2010). "Sekilas tentang Bawean". [online] Retrieved from Penadarisma:https://penadarisma.wordpress.com/media/sekilastentang-Bawean.

[4] Lancaster, K. DSLR Cinema : Crafting the Film Look with Large Sensor Video. Focal Press. (2013). 